\title{
Original Article \\ Phytochemical Study On The Flower of Alstonia macrophylla Wall. ex G.Don (Apocynaceae) from Sumbawa Island, Indonesia
}

\author{
Putri Sri Andila*, Tri Warseno, I Putu Agus Hendra Wibawa, I Gede Tirta \\ Bali Botanical Garden, Indonesian Institute of Science, Bali, Indonesia
}

\begin{abstract}
Alstonia macrophylla Wall. ex G.Don is a native plant to South East Asia, belonging to Alstonia genus. This species has been reported to have numerous natural chemical compound which perfom multiple pharmacological and biological activities. The aim of this study was to investigated the phytochemical properties of the acetone extract of the flower of Alstonia macrophylla Wall. ex G.Don. This is very interesting because phytochemical properties of its flower had been never reported yet. Alstonia macrophylla was harvested from the Natural Forest of Punik, Batu Dulang Village, Batulanteh Subdistrict, Sumbawa Regency, West Nusa Tenggara, Indonesia on Mei 2015. Acetone flower extract of A. macrophylla was analyzed with a GC-MS method to determine the chemical components. Result of GC-MS chromatogram revealed that there were 30 identified components in this extract. The major compounds were Cycloartenol acetate (17.11\%); 5H-1-Pyrindine (12.44 \%); Lupeyl acetate (10.12\%); Oleic acid (6.08 \%); Benzenesulfonic acid, 4-hydroxy- (4.25\%); p-n-Amylphenol (4.23\%); and 4-Methylindole (4.22 \%). Here, We reported the first study of phytochemical properties of A. macrophylla. This study help to understand further detail the potential of bioactive compound of $A$. macrophylla.
\end{abstract}

Keywords: Acetone Extract, Alstonia macrophylla, Flower, GC-MS, Phytochemical

Received: 30 April 2019 Revised: 10 May 2019 Accepted: 25 June 2019

\section{Introduction}

Natural products are chemical properties derived from a living organism, such as bacteria, animal, and plant. In plant, natural product commonly is produced in the form of secondary metabolites. The secondary metabolite occurs in the various part of plants such as leaves, stem and root. The compound is an importhant material for plant for defencing and protection mechanisms from various infection. Interestingly, the secondary metabolite obtained from plant has various biological activities and contains drug-like properties. Due to this reason, for a long time, the research about discovering and developing new drug compounds from secondary metabolites have been an important resources to be studied (Yuan et. al., 2016). For example, Cragg et al. (2013) reported that approximately $54 \%$ of anticancer drug have been isolated from plants, such as paclitaxel (terpene) from Taxus baccata, vinca (alkaloids) from Catharanthus roseus (Cragg et al., 2013) and extract of Alstonia scholaris (Ahmad et al, 2016).

Alstonia consists of 40-60 species belong to Apocynaceae family. This genus is distributed and native to tropical and subtropical regions in Central America, Australia, Polynesia, Africa, and South East Asia with central diversity in the malesian (Sidiyasa, 1998a). Several species of this genus have been identified to be

* Corresponding Author:

Putri Sri Andila

Bali Botanical Garden, Indonesian Institute of Science, Bali, Indonesia

Phone: +6285210065479 Fax: +623682033171

e-mail: putribot11@gmail.com useful for treatment in various human diseases, such as $A$. macrophylla, A. scholaris, A. boonei, and A. congensis. A. macrophylla is one species of this genus which is locally named Pule Batu in Ambon (Indonesia), Pulai penipu Bukit, sayongan, and pulai daun besar, in Malaysia, Batino in Philippines and Tung fa in Thailand (Cheenpracha et al., 2013, Prosea, 2016). This species is classified as 'Least Concern' according to the IUCN Red List (Sidiyasa, K. 1998) and native to South East Asia with distribution region covers from Sri Lanka, South East Asia, Nicobar Islands, and New Guinea (Prosea, 2016).

In many countries, A. macrophylla has been used in a different kind of traditional medication to treat several human ailments and diseases. Das et al. (2006) reported that local community in India use the A. macrophylla stem bark to medicate various types of human disease, such as urinary infection, stomachache, malaria fever, skin diseases, swelling, and bone fracture. They also use the root of A. macrophylla to treat a bone fracture (Verma et al., 2010) and the leaves and root to break a fever (Elanchezhian et al., 2007; Arora, 2010).

Other literature also indicates that the traditional community in the Little Andaman Island, India consume a decoction of leaves and stem bark of A. macrophylla for treatment some human diseases, among others: stomachache, a different type of skin infections and urinary tract infections (Bhargava, 1983). In the Philippines, the leaf of A. macophylla is traditionally used to treat sprains, bruises, and joints disorder. While its bark is used for the treatment of fever, exhaustion, irregular periods of menstrual cycle, malaria, hepatic disease, bloody diarrhoea, diabetes and worm infection (Wiart, 2006). This practice is almost similar to traditional medication in Thailand. Changwichit et al. (2011) reported that the local people in Thailand use the bark and leaf of $A$. macrophylla for curing some human disorder, such as 
impotent, diarrhoea, cholera, dysentery, fever, irregular menstrual period, and as vulnerary agents for healing and treating wounds. In Indonesia, Lombok, the concentrated aqueous extract of leaves, roots or bark of the young tree of A. macrophylla is used to treat ulcers (Hadi and Bremner, 2001).

The recent studies in pharmacology showed that $A$. macrophylla had a different type of pharmacological and biological activities. Keawpradub et al. (1999) revealed that the methanol extract of the root bark of A. macrophylla had antimalaria activity. While the stem bark extracts of A. macrophylla exhibited antiprotozoal (Camacho et al., 2003) and antimicrobial activity (Chattopadhyay et al., 2001; Khyade and Vaikos, 2010). Previous literature also performed that the leaves extract of A. macrophylla had several pharmacology and biology potentials, such as antimicrobial (Chattopadhyay et al., 2001), antioxidant (Arunachalam et al., 2009), Antiinflammatory (Arunachalam et al., 2002, Chattopadhyay et al., 2005a), Antipyretic (Chattopadhyay et al., 2005b), central nervous system drug (Chattopadhyay et al., 2004),

\section{Methods}

\section{Plant Materials and Sample preparation}

The flowers of A. macrophylla were collected from the Natural Forest of Punik, in Batudulang village on Mei 2015. This village is located in the area of Batulanteh Regency, Sumbawa Island, West Nusa Tenggara Province, Indonesia with an altitude 965 meter above sea level and geographical point: S $08^{\circ} 35^{\prime} .866^{\prime \prime}$ and E117 $14^{\prime} 501^{\prime \prime}$ (Shown in Figure 1). The plant was identified by $\mathrm{Mr}$ Ida Bagus Ketut Arinasa, M.Si, a taxonomist of Bali Botanic Garden and the herbarium was saved in the herbarium of Tabanan Hortus Botanicus Baliense (THBB).
Antifertility (Chattopadhyay et al., 2005c) and antidiabetic (Arai et al., 2010).

Several phytochemical studies in the different organ of A. macrophylla have been reported in scientific journals, such as Khyade et al. (2014) published that in leaves extract of $A$. macrophylla contained a various chemical contents, as well as terpenoid, alkaloid, sterol, and flavonoid. But the studies about secondary metabolite compound from the flower of A. macrophylla have never been published yet. Therefore, this study aimed to collect more information on the chemical composition of the acetone extract of A. macrophylla flower from The Natural Forest of Punik, the village of Batudulang, Subdistrict of Batulanteh, Regency of Sumbawa, West Nusa Tenggara, Indonesia.The results of this study were expected to explore further detail information and potential in phytochemical contents in A. macrophylla flower.

\section{Extraction}

One kilogram of fresh material of the A. macrophylla flowers were prepared and minced into small pieces (about $1 \mathrm{~cm}$ in size). Then, the material was dried until perfectly dry at room temperature and without direct sunlight. One hundred grams of the dried materials were extracted with acetone by maceration method (soaking for three days in acetone) and the suspension was obtained by filtering the acetone extract with the filter paper (Azwanida, 2015). This suspension was analyzed with a GC-MS method to identify the name of phytochemical compounds.

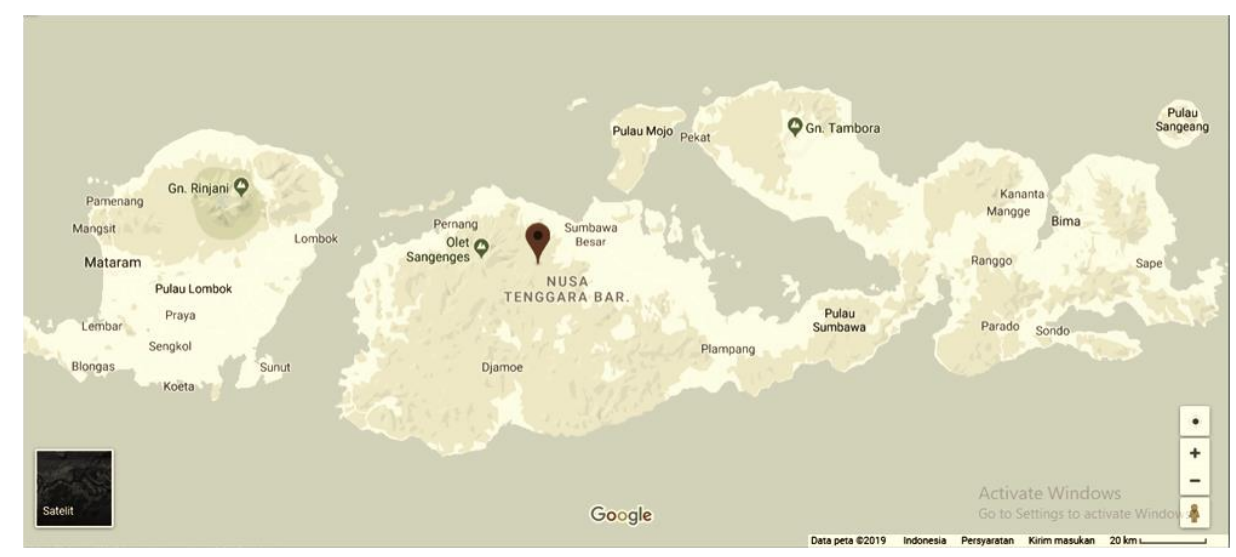

Figure 1. Location of the sampling sites of Alstonia macrophylla, in The Punik Natural Forest, Batu Dulang Village, Batulanteh Subdistrict, Sumbawa Regency, West Nusa Tenggara, Indonesia (Google Maps 2019).

GC-MS Analysis and Identification of the Compounds

The GC-MS analysis of the acetone extract of the $A$. macrophylla flowers was conducted using GC-MS equipment "Shimadzu GC-MS - QP2010". The chromato-graphic column was equipped with Rtx $5 \mathrm{~ms}$, and capillary column $60.0 \mathrm{~m} \times 25 \mathrm{~mm}$ with $0.25 \mu \mathrm{m}$ thickness. In Gas Chromatography Setting, the helium UHP was used as carrier gas at a total flow rate of $46.5 \mathrm{~mL} / \mathrm{min}$, and the column flow rate of $0.85 \mathrm{~mL} / \mathrm{min}$. The total volume of sample injection was $1 \mu \mathrm{L}$ and the temperature of injector was maintained at $280{ }^{\circ} \mathrm{C}$ (with split ration 1:50). The column oven temperature was arranged at 50 ${ }^{\circ} \mathrm{C}$ for $\pm 5 \mathrm{~min}$ then raised to $280{ }^{\circ} \mathrm{C}$, with total running time $50 \mathrm{~min}$ and pressure $101.0 \mathrm{Kpa}$. While the mass spectrum (MS) was set up with the ion source temperature 
$200{ }^{\circ} \mathrm{C}$, interface temperature $280{ }^{\circ} \mathrm{C}$, and detector temperature: $280^{\circ} \mathrm{C}$ (Andila et al., 2019).

\section{Data Analysis}

The relative concentration of each component in the GC-MS result was obtained by comparing the peak area to the total peak area. The identification of chemical compounds identity was conducted using WILEY7 database (Andila et al., 2019).

\section{Results}

The GC-MS analysis result of the acetone extract of the A. macrophylla flowers was shown in table 1 and the GC-MS chromatogram was performed in figure 2. In this study was obtained 30 identified chemical compounds with dominant components were Cycloartenol acetate $(17.11 \%)$; 5H-1-Pyrindine (12.44 \%); Lupeyl acetate (10.12\%); Oleic acid (6.08\%); Benzenesulfonic acid, 4hydroxy- (4.25\%); p-n-Amylphenol (4.23\%); and 4Methylindole (4.22\%).

Table 1. The result of GCMS analyses obtained from the acetone extract of the A. maccrophylla flower from The Punik Natural Forest, Batu Dulang Village, Batulanteh Subdistrict, Sumbawa Regency, West Nusa Tenggara, Indonesia

\begin{tabular}{|c|c|c|c|c|}
\hline Peak & $\begin{array}{c}\text { Compounds of the acetone extract of the Alstonia } \\
\text { macrophylla flowers }\end{array}$ & R.Time & SI & Relative Conc. \% \\
\hline 1 & Benzenesulfonic acid, 4-hydroxy- & 9.773 & 95 & 4.25 \\
\hline 2 & 1-Limonene & 10.132 & 94 & 2.46 \\
\hline 3 & $\mathrm{n}$-(methyl-d2)-aniline & 11.075 & 82 & 1.62 \\
\hline 4 & 2,3-dihydro-benzofuran & 12.744 & 82 & 1.24 \\
\hline 5 & Benzenepropanenitrile & 12.858 & 88 & 0.75 \\
\hline 6 & Safrole & 13.292 & 93 & 1.31 \\
\hline 7 & 5h-1-pyrindine & 13.487 & 83 & 12.44 \\
\hline 8 & 1-Iodo-2-methylundecane & 14.095 & 85 & 1.33 \\
\hline 9 & 4-Methylindole & 14.342 & 95 & 4.22 \\
\hline 10 & 5-Methylquinoxaline & 14.763 & 80 & 1.15 \\
\hline 11 & .beta.-Isodurylonitrile & 15.127 & 73 & 1.93 \\
\hline 12 & 2,3-Dimethylindole & 15.258 & 91 & 1.20 \\
\hline 13 & $\begin{array}{l}\text { Benzene, [(1-methylethylidene)cyclopropyl]-, } \\
\text { (R)- }\end{array}$ & 15.458 & 76 & 2.11 \\
\hline 14 & Lauric acid & 15.628 & 85 & 1.77 \\
\hline 15 & Hexadecane & 15.743 & 84 & 2.03 \\
\hline 16 & 12-methyl-oxa-cyclododecan-2-one & 15.921 & 67 & 1.97 \\
\hline 17 & $\begin{array}{l}\text { tetrahydro-4-(2-methyl-1-propene-3-yl)-2h- } \\
\text { pyran-2-one }\end{array}$ & 16.245 & 83 & 1.65 \\
\hline 18 & Psoralene & 17.060 & 63 & 3.20 \\
\hline 19 & Palmitonitrile & 18.022 & 88 & 2.00 \\
\hline 20 & Oleic acid & 18.444 & 92 & 6.08 \\
\hline 21 & $\begin{array}{l}\text { 1,4-diaza-2,5-dioxo-3-isobutyl bicy- } \\
\text { clo[4.3.0]nonane }\end{array}$ & 18.642 & 89 & 1.49 \\
\hline 22 & 10-methyleicosane & 19.172 & 94 & 1.18 \\
\hline 23 & amide 16 & 19.839 & 91 & 1.69 \\
\hline 24 & Tetracosane & 20.325 & 97 & 1.16 \\
\hline 25 & Oleoamide & 21.031 & 83 & 0.69 \\
\hline 26 & p-n-Amylphenol & 24.029 & 86 & 4.23 \\
\hline 27 & $\begin{array}{c}\text { 4,4,6a,6b,8a,11,11,14b-octamethyl- } \\
1,4,4 \mathrm{a}, 5,6,6 \mathrm{a}, 6 \mathrm{~b}, 7,8,8 \mathrm{a}, 9,10,11,12\end{array}$ & 28.378 & 87 & 3.21 \\
\hline 28 & Cycloartenol acetate & 29.260 & 71 & 17.11 \\
\hline 29 & 5.beta.-pregna & 30.681 & 71 & 1.49 \\
\hline 30 & Lupeyl acetate & 42.248 & 88 & 10.12 \\
\hline & Total & & & 97.08 \\
\hline
\end{tabular}

Note: R.Time: Retention Time, Relative Conc. \%: , Relative Concentration of each detected compounds of a total compound, SI: Similarity Index 


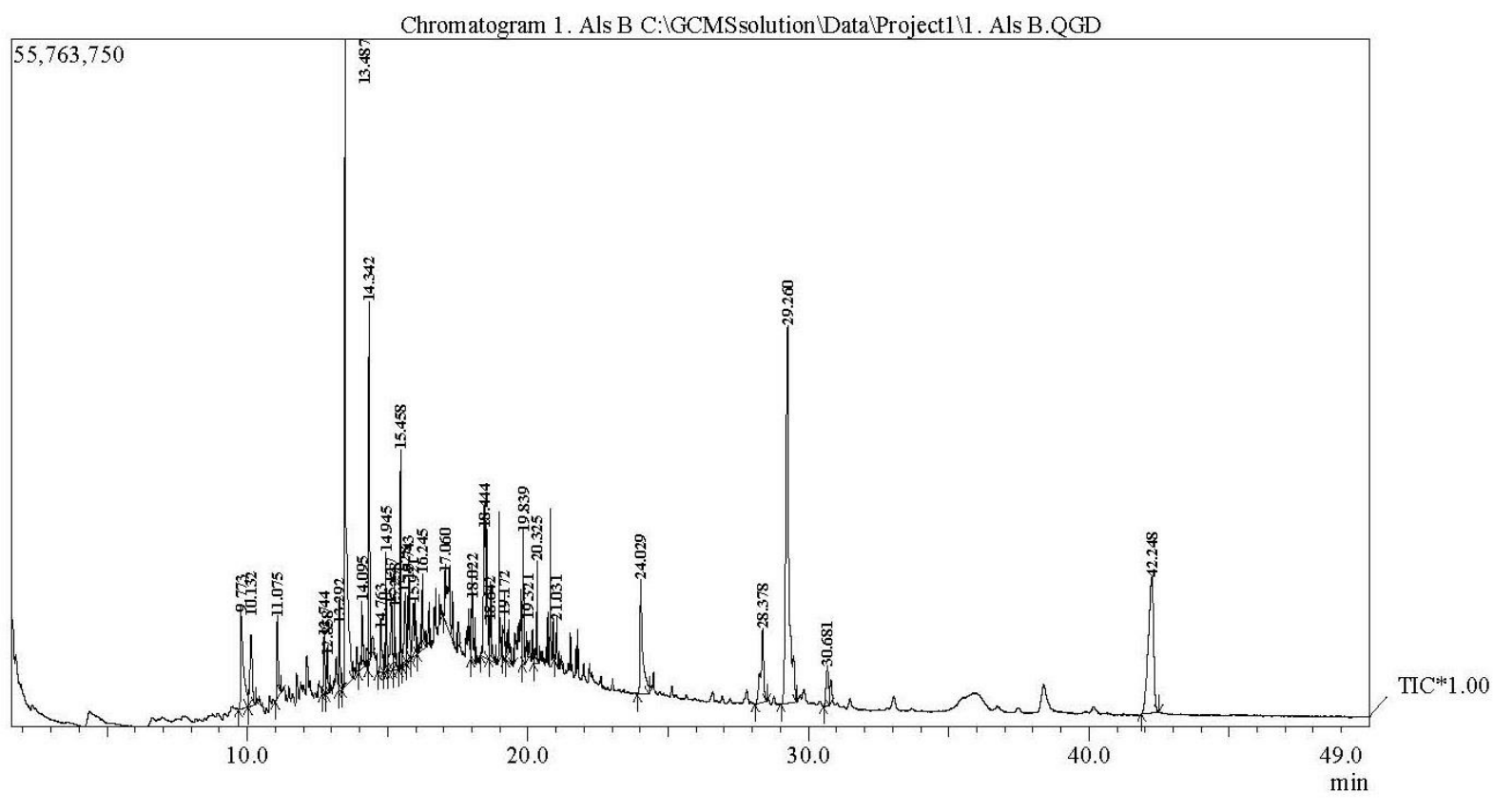

Peak Report TIC

Figure 2. GC-MS chromatogram of the acetone extract of the A. macrophylla flower from The Punik Natural Forest, Batu Dulang Village, Batulanteh Subdistrict, Sumbawa Regency, West Nusa Tenggara, Indonesia

\section{Discussion}

The GC-MS analysis was used to determine the phytochemical properties in the acetone extract of the flower of A. macophylla obtained from the Natural forest of Punik, Batudulang village, Sumbawa regency, West Nusa Tenggara Province. The list of GC-MS analysis result was given in Table 1 . and the chromatogram was perfomed in figure 2. The chromatogram showed 30 peaks in the total peak area, indicating the presence of 30 phytochemical contents. In this research, several terpenoid and fatty acid compounds were found, among others : Cycloartenol acetate 17,11 \% (Triterpene), Lupeyl acetate $10.12 \%$ (Triterpene), 1-Limonene $2.46 \%$ (Cyclic monoterpene), Lauric acid $1.77 \%$ (fatty acid), Oleic acid $6.08 \%$ (fatty acid), oleoamide $0.69 \%$ (fatty acid), and p-n-Amylphenol $4.23 \%$ (fatty acid).

As far as the author's knowledge, this study was the first report about phytochemical properties of A. macrophylla flower. By comparing with previous literature, the chemical properties identified from the flower extract of A. macrophylla were very different with the chemical contents from other part of A. macrophylla. For example, the previous study showed that $A$. macrophylla was abundant in alkaloids and nearly 70 alkaloid compounds were found in A. macrophylla (Khyade et al., 2014), but there were no alkaloid compounds that had been determined from its flower extract. A number of alkaloids had been found and isolated from leaves of $A$. macrophylla, among others : Nb-Demethylalstophylline oxindole (Atta-ur-Rahman et al., 1987), 16-Hydroxy-Nbdemethylalstophylline oxindole, Na-Methyl-1,2dihydrostrictamine (Atta-ur-Rahman et al., 1988), Alstonamide, Alstoumerine, Demethoxyalstonamide
(Atta-ur-Rahman et al., 1991), Alstofoline, Alstonoxine A, Alstonoxine B, N(1)-Demethylalsonisine, Isoalstonisine, Macrogentine, N(1)-Semethylalstonal ( Kam and Choo, 2000), Alstohentine, Alstomicine, Alstomaline, Alstophyllal (8), 6-Oxoalstophylline; 10,11 Dimethoxynareline, 16-Hydroxyalstonisine, 16Hydroxyalstonal, 16-Hydroxy-N(4) demethylalstophyllal oxindole, 6 Oxoalstophyllal (Kam and Choo, 2004), and Alstiphyllanines A-D (Hirasawa et al., 2009), Alstonal, Alstonerine, Alstiphyllanines E-I, Burnamine-17-O30,40,50; trimethoxybenzoate, O-Deacetylpicraline, 10Methoxy-N(1)-methylburnamine-17-O, veratrate, Picralina, Picrinine, Quaternine, Veratrate, Vincamedine, Vincamajine, and Vincamajine-17-O-trimethoxybenzoate (Arai et al., 2010). While the alkaloids found in stem bark of A. macrophylla were Macralstonine, Naresuanoside, Sweroside, Thungfaine (Changwichit et al., 2011), Alstoniaphylline A-C (Cheenpracha et al., 2013), Alstonerinal, 10-Methoxyaffinisine, 10Methoxycathafoline (Kam et al., 1999), Angustimalal, N(1)-Demethylalstophylline $\quad 14, \quad$ N(1)Demethylalstophyllal, Macrocarpine A, Macrocarpine B, Macrocarpine C, Macrodasine A, Macrodasine B, N(4)Methyl-N(4), 21, secotalpinine, Perhentinine (Kam et al., 2004), Lumutinines A-D, Perhentidines A-C (Lim et al., 2011), Alstonal, Nb-Demethylalstophyllal oxindole, $\mathrm{Nb}$ Demethylalstophylline Talcarpine (Wong et al., 1996). In root bark of A. macrophylla was also contained some alkaloid compounds such as Alstomacrophylline, Alstomacroline, Alstonerine Alstophylline, 20-epiAntirhine, Macrocarpamine, Villastonine N-oxide (Keawpradub and Houghton, 1997). 
Besides Alkaloid, other groups of bioactive compound have also been found in leaves of $A$. macrophylla, among others: flavonoid (such as: Myricetin-30-rhamnoside-3-Ogalactoside, Tricin-40-O- $\beta$-L-arabinoside, Vitexin) (Parveen et al., 2010), Pytosterols (such as $\beta$-sitosterol and $\beta$-sitosterol glucoside) and Triterpenoids (Ursolic acid, Pytosterols $\beta$-sitosterol and $\beta$-sitosterol glucoside) (Arunachalam et al., 2009).

\section{Acknowledgments}

We would like to express our special thank and appreciation to the essential oil research group at "Eka Karya" Botanical Garden- Bali for sponsoring this study (DIPA-2016). We also give our gratitude to Ida Bagus Ketut Arinasa, M.Si for his input in this research. We (Authors) also declare that Putri Sri Andila and Tri Warseno play a role as a main contributor in this study, while I Putu Agus Hendra Wibawa and I Gede Tirta are a member contributor.

\section{References :}

Ahmad, S., Ahmad, S., Ali, A., \& Afzal, M. (2016). Anticarcinogenic and antimutagenic activity of Alstonia scholaris on the albino mice bone marrow cells and peripheral human lymphocyte culture against methyl methane sulfonate induced genotoxicity, 5(92), Advanced Biomedical Research. 1-11.

Andila, P. S., \& Tirta, I. G. (2019). Distribution and Phytocomponent in the Ethanol Extract of Globba candida Gagnep . Zingiberaceae ) by GC-MS Analysis. Journal of Tropical Life Science 9(1), 43-51.

Arai, H., Hirasawa, Y., Rahman, A., Kusumawati, I., Cholies, N., Sato S. \& Morita, H. (2010). Alstiphyllanines E - H , picraline and ajmaline-type alkaloids from Alstonia macrophylla inhibiting sodium glucose cotransporter. Bioorganic \& Medicinal Chemistry 18(6), 2152-2158

Cheenpracha, S., Ritthiwigrom, T., \& Laphookhieo, S. (2013). Alstoniaphyllines A - C , Unusual Nitrogenous Derivatives from the Bark of Alstonia macrophylla. Journal of Natural Products 76(4), 723-726.

Cragg, G. M., \& Newman, D. J. (2013). A continuing source of novel drug leads. Biochimica et Biophysica Acta 1830(6), 3670 3695 .

Das, S., Sheeja, T. E., \& Mandal, A. B. (2006). Ethnomedicinal uses of certain plants from Bay Islands Ethnomedicinal uses of certain plants from Bay Islands. Indian Journal of Traditional Knowledge 5(2), 207-2011.

Elanchezhian, R, Senthil Kumar, R., Beena, S.J., \& Suryanarayana, M.A. (2007). Ethnobotany of Shompens - A primitive tribe of Great Nicobar Island Ethnobotany of Shompens - a primitive tribe of Great Nicobar Island. Indian Journal of Traditional Knowledge 6(2), 342-345.

Guha Bakshi, D.N. \& Sensarma, P., Pal, D.C. (1999). A Lexicon of Medicinal Plant in India. Vol. 2. Kolkata, India: Naya Prakash.

Hadi, S \& Bremner, J.B. (2001). Initial studies on alkaloids from Lombok medicinal plants. Molecules 6(2), 117-129.

Hirasawa, Y., Arai, H., Zaima, K., Oktarina, R., Rahman, A., Ekasari, W., Widyawaruyanti, A., Indrayanto, G., Zaini, N.C. \& Morita, H. (2009). Alstiphyllanines A - D , Indole Alkaloids from Alstonia macrophylla. Journal of Natural Product 72(2), 304 307.

Kam, T. \& Choo, Y. M. (2004). New Indole Alkaloids from Alstonia macrophylla. Journal of Natural Product 64(7), 547-552.

Kam, T., Iek, I., Choo, Y., Silva, D., Silva, D., Silva, D., \& Kam, M. A. (1999). Alkaloids from the stem-bark of Alstonia macrophylla. Phytochemistry 51(6), 839-844.

Keawpradub, N \& Houghton, P. (1997). Indole alkaloids from Alstonia macrophylla. Phytochemistry 46(4), 1-5.
Keawpradub, N., Kirby, G. C., Steele, J. C. P., \& Houghton, P. J. (1999). Antiplasmodial Activity of Extracts and Alkaloids of Three Alstonia Species from Thailand. Planta Medica 65(8), 690-694

Khyade, M.S., Kasote, D.M. \& Vaikos, N. P. (2014). Review: Alstonia scholaris (L.) R. Br. and Alstonia macrophylla Wall. ex G. Don: A Comparative Review on Traditional Uses, Phytochemistry and Pharmacology. Journal of Ethnopharmacology 153, 1-18.

Khyade, MS, Vaikos, N. (2010). Comparative phytochemical and antibacterial studies on the bark of Alstonia scholaris R. Br. and Alstonia macrophylla Wall. ex G. Don. Pharmaceutical Journal $1(4), 263-264$

Lim, S.H., Tan, S.J., Low, Y.Y. \& Kam T.S. (2011). Lumutinines A D, linearly fused macroline_macroline and macroline_sarpagine bisindoles from Alstonia macrophylla. Journal of Natural Product 74(12), 2556-2562.

Parveen, M., Khanam, Z., Akhtar, A. \& Ahmad, S. M. (2010). A nove antimicrobial flavonoidic glycoside from the leaves of Alstonia macrophylla Wall ex A. DC (Apocynaceae). Chinese Chemical Letters 21(5), 593-595.

PROSEA. (2016). Alstonia macrophylla. Retrieved from https://uses.plantnetproject.org/e/index.php?title=Alstonia_mac rophylla_(PROSEA)\&oldid=218663.

Sidiyasa, K. (1998). Alstonia macrophylla. The IUCN Red List of Threatened Species 1998: e.T33194A9760084. Retrieved from http://dx.doi.org/10.2305/IUCN.UK.1998.RLTS.T33194A9760 084.e

Sidiyasa, K. (1998). Taxonomy, Phylogeny, and Wood anatomy of Alstonia (Apocynaceae). Blumea. Supplement 11(1), 1-230.

Wiart, C. (2006). Medicinal Plants of the Asia-Pacific: Drugs for the Future. Singapore: World Scientific Publishing Co. Pte. Ltd.

Wong, W., Lim, P., \& Chuah, C. (1996). Oxindole alkaloids from Alstonia macrophylla. Phytochemistry 41(1), 313-315.

Yuan, H., Ma, Q., Ye L. \& Piao, G. (2016). The Traditional Medicine and Modern Medicine from Natural Products. Molecules 21(5), $1-18$. 